\title{
Epithelial-Mesenchymal Transition: A Hallmark in Metastasis Formation Linking Circulating Tumor Cells and Cancer Stem Cells
}

\author{
Magdalena Książkiewicz ${ }^{a} \quad$ Aleksandra Markiewicz $^{a}$ b Anna J. Żaczek ${ }^{a}$ \\ a Laboratory of Cell Biology, Department of Medical Biotechnology, Intercollegiate Faculty of Biotechnology, \\ University of Gdańsk and Medical University of Gdańsk, Gdańsk, and b Postgraduate School of Molecular Medicine, \\ Medical University of Warsaw, Warsaw, Poland
}

\section{Key Words}

Breast cancer • Epithelial-mesenchymal transition •

Cancer stem cells $\cdot$ Circulating tumor cells

\begin{abstract}
The occurrence of either regional or distant metastases is an indicator of poor prognosis for cancer patients. The mechanism of their formation has not yet been fully uncovered, which limits the possibility of developing new therapeutic strategies. Nevertheless, the discovery of circulating tumor cells (CTCs), which are responsible for tumor dissemination, and cancer stem cells (CSCs), required for tumor growth maintenance, shed light on the metastatic cascade. It seems that CTCs and CSCs are not necessarily separate populations of cancer cells, as CTCs generated in the process of epithelialmesenchymal transition (EMT) can bear features characteristic of CSCs. This article describes the mechanisms of CTC and CSC formation and characterizes their molecular hallmarks. Moreover, we present different types of EMT occurring in physiological and pathological conditions, and we demonstrate its crucial role in providing CTCs with a CSC phenotype. The article delineates molecular changes acquired by cancer cells undergoing EMT that facilitate metastasis formation. Deeper understanding of those processes
\end{abstract}

is of fundamental importance for the development of new strategies of early cancer detection and effective cancer treatment approaches that will be translated into clinical practice.

Copyright $\odot 2012$ S. Karger AG, Base

\section{Introduction}

Distant metastasis development is the main cause of death in cancer. Metastatic lesions are hardly manageable in clinical practice as they are often too widespread or too large to be removed by surgery and frequently exhibit increased resistance to chemotherapy. Thus the understanding of the metastasis process is of key significance for treatment improvement and decreasing the death rate of cancer patients.

In order to progress, tumors of epithelial origin need to acquire features which enable them to: (1) loosen cellcell contact, breach the basal membrane and dissociate from the tumor mass, (2) invade neighboring tissue, intravasate into blood or lymph vessels and (3) extravasate

M.K. and A.M. contributed equally to this work.

\section{KARGER}

Fax +4161306 1234

E-Mail karger@karger.ch

www.karger.com (c) 2012 S. Karger AG, Basel

$1015-2008 / 12 / 0794-0195 \$ 38.00 / 0$

Accessible online at:

www.karger.com/pat
Anna J. Żaczek

Laboratory of Cell Biology, Department of Medical Biotechnology, Intercollegiate Faculty of Biotechnology, University of Gdańsk and Medical University of Gdańsk Dębinki 1, PL-80 211 Gdańsk (Poland)

Tel. +48 58349 1438, E-Mail azaczek@gumed.edu.pl 
from vessels in distinct organs to create secondary tumor(s) [1]. Epithelial tumor cells gain invasiveness and migratory abilities in the process of epithelial-mesenchymal transition (EMT), which is essential for successful metastatic spread $[2,3]$. The process of EMT is very likely to be responsible for drug efficiency decrease and thus anticancer therapy failure. Moreover, it appears that stem-like cells can arise as a result of EMT $[4,5]$. Circulating tumor cells (CTCs), isolated from the blood of breast cancer patients, may be linked to both cancer stem cells (CSCs) and EMT processes as they can possess features of CSCs as well as phenotypic changes characteristic of EMT [6-9]. Altogether, these cells are predestined to be an active source of metastases due to their potential stem cell features and EMT traits which allow them to disseminate effectively.

A considerable effort has been dedicated to elucidating the molecular background of tumor invasion and metastasis, and an enormous amount of data on the subject has been generated. Here we review the emerging picture of EMT as the hallmark in metastasis formation, linking both circulating tumor cells and the formation of cells with cancer stem cell phenotypes. We delineate the clinical significance of CTCs as such and their molecular characteristics as predictive and prognostic tools in cancer management.

\section{EMT in Physiology and Pathophysiology}

EMT is a multi-step process involving molecular and cellular changes in epithelial cells. Restrained and immobile epithelial cells gain a mesenchymal phenotype, characterized by an enhanced motility and ability to degrade ECM [10-15]. This leads to the weakening of cell-cell adhesion due to the downregulation of epithelial proteins, mainly E-cadherin but also claudins, occludins and cytokeratins [2, 15-17]. Cells that have undergone EMT show changes in apicobasal polarity which leads to a spindleshaped morphology $[18,19]$. The characteristic features of a mesenchymal phenotype are high expression of $\mathrm{N}$ cadherin as well as fibronectin, vimentin, tenascin C, collagen VI- $\alpha$ and laminin- $\beta 1[13,16,17,20,21]$. These changes observed in the EMT process are governed by transcription factors such as TWIST1, SNAIL, SLUG, SIP1 $[14,22]$. To date a number of different EMT inducers such as Wnt, Hedgehog, EGF and TGF- $\beta$ have been unveiled $[23,24]$ and molecular pathways have been delineated. For example, the binding of TGF- $\beta$ to proteins expressed on the surface of breast cancer cells activates the expression of SNAIL and SLUG which suppress E-cadherin expression [25].

EMT plays a critical role in a number of physiological and pathophysiological conditions. Depending on the mechanisms, different classes of EMT have been proposed: embryonic and developmental EMT referred to as type I, fibrotic and wound-healing EMT referred to as type II and cancer progression EMT known as type III [11-14, 26, 27].

EMT type I (classic EMT) besides embryonic development also occurs during postnatal growth. Furthermore, it plays a role in maintaining epithelial homeostasis. The steps of EMT during this process are specific and well defined. Normal epithelial cells are cuboidal and remain in contact with each other through adherent and tight junctions. They are also attached to the basal membrane by integrins. Adherent junctions are composed mainly of E-cadherin, catenins and actin, while claudin and occludins are more characteristic of tight junctions. EMT inducers downregulate the expression of the components of both tight and adherent junctions, which results in loosening of the apicobasal polarity of the cells and disassembling of the basal membrane $[28,29]$. This process is accompanied by changes in the cytoskeleton, such as the replacement of peripheral actin elements by stress fibers, which are crucial for cells to liberate from the epithelium and acquire migratory properties $[22,30]$. All the aforementioned changes, together with simultaneous protease activity, lead to cell delamination and invasion [31]. Primary mesenchymal cells generated in this way have the potential to subsequently go through the process of mesenchymal-epithelial transition (MET), the reverse of EMT, and thus generate secondary epithelia [27]. During embryonic development, cells may undergo EMT a number of times; hence, almost all organs in adults arise as a result of one or several rounds of EMT followed by MET.

The ability of cells to undergo the process of EMT and subsequently reverse is called epithelial plasticity. A unique example of this phenomenon is the postnatal development of the mammary gland. The developmental cycle of the breast is long-lasting, since the mammary gland achieves its full dimensions after the first lactation during mammary gland involution. During this complex organ evolution, epithelial cells need to go through many rounds of proliferation, invasion and cell death [32, 33].

EMT type II (fibrotic EMT) is triggered by injury and mainly generates fibroblasts in order to reconstruct wounded tissues $[3,12,34,35]$. In physiological conditions fibroblasts and immune cells release inflammatory factors (e.g. different cytokines) and extracellular matrix 
Fig. 1. The role of EMT in cancer invasion. Two models have been proposed for EMT involvement in cancer metastasis. After stimulation, carcinoma cells activate a program of EMT and phenotypical changes occur, leading to the formation of either a pure population of highly invasive mesenchymal-like cells or sets of cell clusters with 'hybrid' phenotypes. Model A: after undergoing full EMT, mesenchymal-like cancer cells disseminate from the tumor mass and reach the circulatory system. Once they extravasate in a distant organ, they undergo MET and create metastases $[12,50]$. Model B: cancer cells disseminate and migrate as clusters of cells with different phenotypes; cancer cells that pass through full EMT lead the partial EMT and non-EMT cells. All cell types enter the circulation, but only non-EMT cancer cells are able to extravasate and create metastases [55].

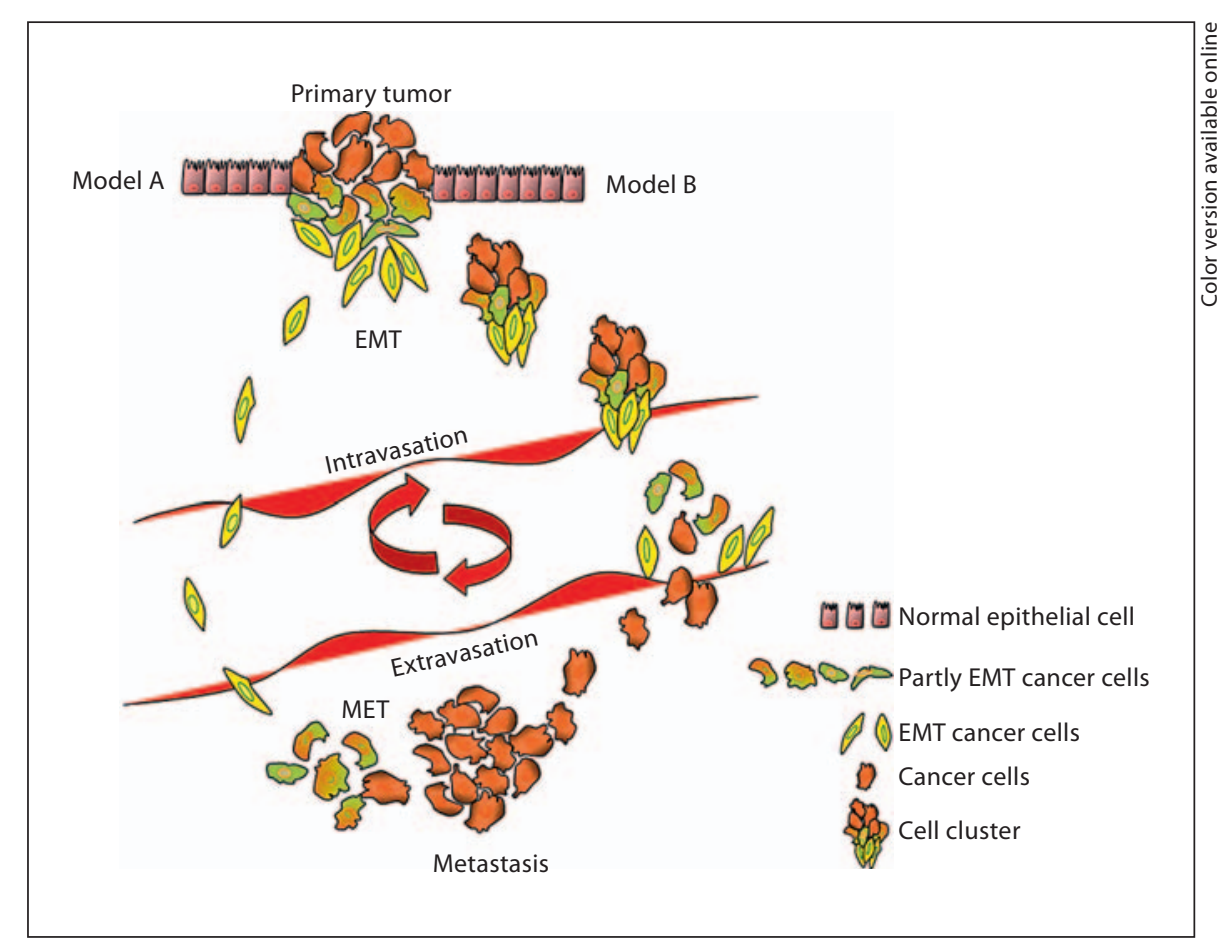

proteins which stimulate cells to undergo EMT. Once the inflammation subsides the process is terminated. Under pathological conditions of persistent inflammation, continuous EMT of normal epithelial cells can lead to fibrosis and organ (lung, liver, kidney) damage [3, 12, 34-37].

Similarly to fibrosis, the oncogenic process can disturb homeostasis in cells and induce EMT type III. The oncogenic EMT enables epithelial cells to acquire motile and invasive phenotype characteristics for mesenchymal cells, which is essential in metastatic cascade [2]. Many EMT features typical for development are present in oncogenic EMT, however, they are less ordered and coordinated. Although it seemed to be predictable that the same mechanism could be responsible for the delamination of cells, both in the development and metastatic spread of epithelial cancers, the contribution of the EMT process to tumor progression has only recently been commonly accepted [38-40]. This was caused by the transient character of EMT in tumors and technical difficulties in identifying migrating cancer cells on pathological specimens $[4,41-43]$. EMT occurs in restricted places within a tumor (such as a leading edge [44]) and the micrometerthick slices allow observation of only a limited area of a tumor cross section. However, the altered shape of tumor cells and the process of intravasation have been shown in vivo in animal models using intravital microscopy, which allows real-time monitoring of fluorescently labeled tumor cells, and adjustment of the depth of focus and contrast [45]. Moreover, the lack of direct clinical evidence for EMT in cancer was boosted by the observation that secondary tumor sites histopathologically resemble cells of the primary tumor from which they originated. This can be explained by the occurrence of the MET process once tumor cells have extravasated into distant organs [27]. Disseminated cancer cells need to regain their epithelial phenotype in order to initiate the growth of a solid tumor at the secondary site. The studies of Chao et al. [46] demonstrated that the secondary organ microenvironment can induce the process of MET in the mesenchymal-like MDA-MB-231 breast cancer cell line and in primary explants by reexpression of E-cadherin. A few other studies have described the phenomenon of a switch between EMT and MET in bladder, colorectal and ovarian cancer [39, 47, 48] (fig. 1, model A). It should also be mentioned that changes between epithelial and mesenchymal phenotype in carcinoma cells may lead to the arising of hybrid phenotypes which 'accumulate' features of both cell types $[18,49,50]$. Cells do not need to undergo a full transition to a mesenchymal phenotype or even to show any changes typical of EMT. In fact, they can stay morphologically well differentiated and take part in the metastasis process. This process is known as 'collective' 
or 'cohort' migration in which cells do not disseminate and invade as individuals but as multicellular clusters. It is possible that in the cluster of migrating cells many intermediates between epithelial and mesenchymal phenotypes coexist. The invasive front of the tumor consists of mobile invasive cells resulting from EMT, followed by unchanged tumor cells with epithelial characteristics [5052]. This type of cell migration occurs both in breast cancer and during regular development $[53,54]$. An interesting model of collective migration in cancer was described by Tsuji et al. [55] where only cooperation between EMT and non-EMT cancer cells enabled a successful process of metastasis. EMT cells with an invasive phenotype, responsible for matrix degradation and penetration of local tissue and vessels, lead non-EMT cells and enable their intravasation. Non-EMT cells endowed with adhesive properties are able to attach to the vessel wall and extravasate, successfully creating metastasis (fig. 1, model B). During breast cancer development, both the EMT process and partial EMT can be observed. EMT, for example, is representative of infiltrating lobular carcinoma. Partial EMT manifests itself as cell cohorts and partially dedifferentiated tubules found in invasive ductal carcinoma [50]. The existence of more than one cellular mechanism for tissue invasion is obvious both in branching morphogenesis and in epithelial cancers; however, a lot of effort must be put into understanding the dependence of these processes.

\section{Cancer Stem Cells and Metastasis}

In the last decade the understanding of the metastasis process has changed considerably. A stochastic model of tumor development and maintenance was challenged by 'cancer stem cell hypothesis' [56-58]. The stochastic model assumes that all cells in cancer are equally malignant and every single cell has the potential of reconstituting a primary tumor under favorable circumstances, although the probability of this event is low $[59,60]$. According to this concept, heterogeneity within the population of tumor cells develops during tumor progression due to the effect of genomic instability and the accumulation of mutations. Then, in the process of clonal selection, the tumor is enriched for cells endowed with metastatic properties, which can disseminate and form secondary tumors $[61,62]$. 'Cancer stem cell hypothesis' implies the preexistence of functional heterogeneity within tumor cells with a discrete subpopulation of CSCs, able to initiate and maintain tumor growth and bulk nontumorigen- ic cells [57, 58, 63-66]. Evidence for the existence of CSCs was first reported by Bonnet and Dick [58] in acute myelogenous leukemia, and then shown for breast cancer [57] and other malignancies [64-67]. CSCs are so termed through their analogy with normal stem cells. Similarly, CSCs possess the ability to self-renew in vivo and differentiate. They can give rise to a phenotypically diverse progeny composed of both tumorigenic cells with indefinite proliferation potential and nontumorigenic cells with limited proliferation potential. This way they recreate the whole repertoire of cell subpopulations observed in the original tumor. However, in contrast to normal stem cells, they do not need to exhibit multilineage differentiation ability $[58,68,69]$. In spite of their name, CSCs do not necessarily arise from normal tissue stem cells. They can also originate from more differentiated progenitor cells which underwent transformation [70, 71]. Alternatively, CSCs may arise through an EMT process from transformed epithelial cells and achieve migratory and tumor-spreading properties $[5,72,73]$. In an experimental system, the induction of EMT in immortalized, nontumorigenic human mammary epithelial cells resulted in acquisition of the $\mathrm{CD} 44^{+} / \mathrm{CD} 24^{-/ \text {low }}$ phenotype, characteristic of breast cancer stem cells [4]. CD44 is a cell-adhesion molecule involved in binding cells to hyaluronic acid, whereas CD24 is a negative regulator of the chemokine receptor CXCR4, a molecule involved in breast cancer metastasis [74]. It must be kept in mind that the heterogeneity of tumorigenic ability existing between different types of breast tumors must not necessarily be related only to the $\mathrm{CD} 44^{+} / \mathrm{CD} 24^{-/ \text {low }}$ phenotype. It has been shown that the $\mathrm{CD} 44^{+} / \mathrm{CD} 24^{-/ \text {low }}$ subpopulation of cells is present in most (but not all) basal-like tumors, especially in BRCA1 hereditary breast cancer. However, this subpopulation of cells is present in only a few HER2positive tumors [75]. Ever since Al-Hajj et al. [57] defined the CSC subpopulation in breast cancer on the basis of CD44 and CD24 expression, their status has been examined in other tumors. Cells with the $\mathrm{CD} 44^{+} / \mathrm{CD} 24^{-/ \text {low }}$ phenotype were postulated to be stem-like cells responsible for tumor initiation in non-small cell lung cancer and prostate cancer $[76,87]$. Interestingly, in pancreatic cancer, a subpopulation with a high coexpression of $\mathrm{CD} 24\left(\mathrm{CD} 44^{+} / \mathrm{CD} 24^{+} / \mathrm{ESA}^{+}\right)$was identified as being endowed with tumorigenic activity in NOD/SCID mice [78]. Similarly, in gastric cancer $\mathrm{CD} 44^{+} / \mathrm{CD} 24^{+}$cells were recognized as cells with stemness features [79]. CD44 and CD24 are also listed among colon CSC markers, although combined with CD166 and CD133, respectively [80, 81]. Expression of CD24, CD44 and CD133 is correlated with 
the invasiveness and differentiation of colorectal carcinoma, but not with patient outcome [82]. The list of stemness markers is still growing, both cancer type-specific and universal. Mostly, markers have been identified through the exploration of cell surface proteins and since many of them are important for cellular adherence (CD24, CD133, CD166) they are probably involved in forming new tumors [83]. However, focusing on markers involved only in the cell attachment can be a source of false conclusions since the enhanced ability of these cells to grow in new environments does not necessarily need to be a hallmark of stemness itself. It is also important to identify functional markers for CSCs, to which, for example, ALDH1 belongs (present in breast, colon, pancreatic carcinoma [84-86]) or Wnt $[61,90]$. ALDH1 is a marker for both normal and malignant stem cells and it is thought to have a role in the early differentiation of stem cells $[84,88]$. Within breast cancer cells with a $\mathrm{CD} 44^{+} \mathrm{CD} 24^{-/ \text {low }}$ phenotype, a subpopulation of ALDH1positive cells endowed with a prominent tumor-initiating ability was found. Moreover, expression of ALDH1 alone in breast cancer samples correlated with poor clinical outcome [88]. Other proteins proposed as stemness markers in breast cancer include the following: CD133 [89], OCT-4 [90] and NANOG-1 [91]. OCT-4 is a transcription factor taking part in the self-renewal of undifferentiated embryonic stem cells and its expression can reprogram unipotent stem cells to pluripotent cells [92]. High expression of OCT- 4 was observed in $\mathrm{CD} 44^{+} / \mathrm{CD} 24^{-}$cancer cells isolated from primary breast cancer tumors [93] and in ALDH1-expressing cells of the 4T1 murine breast cancer cell line [94]. OCT- 4 can also act together with another transcription factor involved in the pluripotent state of stem cells - NANOG-1 $[95,96]$ - and their expression is elevated in mammospheres, which are formed by cells enriched for metastatic potential [94, 97]. CD133 function is not yet well understood, however, it might be involved in cell differentiation and epithelial-mesenchymal interaction [98]. CD133-positive breast cancer cells frequently express other stem cell markers - NOTCH1, $A L D H 1, S O X 1, C D 44$ - and are highly tumorigenic in animal models [99].

Features of CSCs such as motility, invasion, survival in circulation, dormancy and ability to interact with micromilieu at a secondary tumor location imply that these cells might be responsible for the development of overt metastasis [56, 100-102]. Such a mechanism, explaining metastatic spread through the existence of mammary stem and progenitor cells already at the beginning of tumor transformation, is supported by experiments em- ploying gene expression profiling. Liu et al. [103] developed a gene signature which consists of 186 genes differentially expressed in normal breast epithelium and in breast $\mathrm{CD} 44^{+} / \mathrm{CD} 24^{-/ \text {low }}$ cells. This signature was significantly correlated with metastasis-free and overall survival. Another study employing microarray analysis of $\mathrm{CD} 44^{+} \mathrm{CD} 24^{-/ \text {low }}$ cells versus $\mathrm{CD} 44^{-} / \mathrm{CD} 24^{+}$cells isolated from breast cancer tumors confirmed that these two subpopulations of cells are genetically distinct from each other, and the gene expression profile of the breast cancer stem cell fraction $\left(\mathrm{CD} 44^{+} / \mathrm{CD} 24^{-/ \text {low }}\right)$ resembles a profile characteristic of stem cells [104]. Analogically to normal breast stem cells, this subpopulation of breast cancer cells was able to form mammospheres in vitro $[4,105]$.

\section{CTCs and Metastasis}

CTCs are cells which manage to separate from the tumor mass and enter the bloodstream. They are defined as tumor cells originating from either primary sites or metastases and circulating freely in the peripheral blood. They have been detected in a majority of epithelial cancers, including those from breast, prostate, ovary, lung and colon, but are extremely rare in healthy people [106]. CTCs may constitute seeds for the subsequent growth of metastasis in distant organs according to Paget's 'seed and soil hypothesis' [107]. However, CTCs may also be capable of self-seeding back to the original organs, which infers increased aggressiveness of the existing tumor [108], or they can settle in other organs such as bone marrow, a point at which they are termed disseminated tumor cells (DTCs) [109] and can serve as a reservoir of tumor cells responsible for future recurrence [110].

CTCs represent a heterogenous population of tumor cells with the potential of forming various metastases. From experimental models it is estimated that about 1 million cells per $1 \mathrm{~g}$ of tumor tissue can spread daily into the bloodstream [111]. In mouse models where cells were injected intraportally, only 1 CTC in 40 was able to establish metastatic foci, and 1 in 100 micrometastases could form a tumor at day 13 after injection [112]. This metastasis inefficiency is mainly the effect of anoikis and explains the low survival rates of CTCs in vessels after leaving the tumor mass [112-114]. Moreover, only some solitary cells which extravasate in distant organs are able to proliferate, and finally, not every established micrometastasis can overcome the step of new vessel formation and develop into macrometastasis [112]. 
The first document describing CTCs in the peripheral blood of cancer patients dates from 1989 [115] and since that moment the interest in the clinical significance of CTCs has been increasing. CTCs are called 'liquid biopsy' since they are a potential alternative to invasive biopsies as a source of tumor material for the detection, characterization and monitoring of nonhematologic cancers. The clinical applications of CTCs are strictly dependent on the development of reliable techniques for CTCs detection.

Despite huge efforts and numerous studies, CTCs detection is still technically challenging, mainly due to their paucity and biological heterogeneity [116]. Currently used approaches for CTCs isolation and detection are based on the properties which distinguish CTCs from abundant blood cells. This includes the presence of specific proteins (CellSearch, CTC-chip, RARE, MagSweeper) and gene transcripts (AdnaTest), size (ISET technology), density (Oncoquick), electric charge, secretion of specific proteins (EPISPOT) or invasive properties [117]. There are many issues concerning reliable CTC detection which are still a matter of debate. They concern the accuracy, sensitivity and specificity of the techniques, the optimal cutoff for CTC enumeration, optimal markers for CTC identification or ability to determine the cell condition (viable or apoptotic, dividing or nondividing). Unfortunately, there is a great interlaboratory variability regarding the techniques used, and no tumor marker identified so far is specific enough to detect rare CTCs. The most widely used approach relies on the epithelial molecule - EpCAM - the expression of which is present in $60-100 \%$ of breast cancers $[118,119]$. However, the study of Sieuwerts et al. [120] showed that EpCAM-based CTC detection does not recognize breast cancer cells belonging to a normal-like subtype, which is characterized by aggressive behavior. This deficiency of assay sensitivity can be overcome by using the additional surface marker CD146, which is frequently expressed on cells lacking EpCAM [121]. Additional drawbacks of the epithelial marker-based isolation and detection methods were revealed when it was discovered that the EMT, which occurs in CTCs, causes downregulation of epithelial markers and renders CTCs undetectable. Therefore, experiments aimed at the analysis of the EMT process itself, or the EMT-induced stemness of CTCs, should not rely solely on a single marker but on a few markers $[122,123]$, and possibly also include mesenchymal markers induced by EMT [116]. There is an urgent need for optimization and clinical validation of the developed techniques of CTC detection and isolation. Progress in this matter will largely depend on better characterization of CTC phenotypes and deeper understanding of the mechanisms involved in their generation and survival.

Currently, it is evidently clear that cells detach from tumors well before a metastasis is clinically visible [124, 125]. Therefore, CTCs enable tracking of one of the first steps in a metastatic cascade and provide great potential for prognosis and monitoring of treatment response in many cancers. The presensce of CTCs was demonstrated to be an independent adverse prognostic factor in metastatic [126-128] and early breast cancer [129], metastatic colorectal cancer [130], castration-resistant prostate cancer $[131,132]$ or resectable non-small cell lung cancer $[133,134]$.

Since CTCs can be obtained repeatedly in a noninvasive manner, they may be used to choose the optimal therapy, predicting the response to it and monitoring its efficacy. The number of CTCs in patients with breast, lung, prostate and other cancers was decreased after the initiation of effective chemotherapy, hormonal therapy or targeted therapy $[125,127,128,135,136]$. Treatmentinduced changes in CTCs numbers measured at different time points were also proven to be a reliable surrogate marker of response to treatment [137-139].

Not only enumeration of CTCs, but also determination of their molecular profiles provides information which is important from a clinical point of view. It was found that CTCs may be genetically different from the primary tumor they derive from, and that the differences might influence patient response to therapies, which are currently prescribed on the basis of the primary tumor characteristics. For example, HER2-positive CTCs were reported in breast cancer patients who had HER2-negative primary tumors, and vice versa, HER2-negative CTCs were observed in patients with HER2-positive tumors [140, 141]. Analogical dissimilarities between CTCs and primary tumors have been demonstrated for epidermal growth factor receptor (EGFR) [142], estrogen receptor alpha, and progesterone receptor [143]. These differences might be explained by the strong selection of a specific cell population during dissemination or by the methodological limitations of a biomarker (such as HER2) determination [116]. In addition, CTCs may also get to the blood circulation from secondary sites [108], and may be similar in genotype and phenotype to the cells from metastatic sites instead of the primary origin.

Moreover, the characterization of CTCs may allow examination of the molecular evolution of tumor cells during the course of treatment, which may be particularly important in monitoring of the development drug resistance [136]. Recently, real-time CTCs genotyping during 
treatment with EGFR-targeted therapies against nonsmall cell lung cancer [136] and breast cancer [144] has been reported. Thus, it seems that treatment decisions may be based on the molecular profile of CTCs. The ongoing analyses of the results of clinical trials, such as the Southwest Oncology Group trial SWOG S0500 (www. clinicaltrials.gov, identifier: NCT00382018) on metastatic breast cancer patients, the German Breast Group GEPARQuattro trial (www.germanbreastgroup.de/en/ trials/neoadjuvant/geparquattro.html) and the SUCCESS trial on nonmetastatic breast cancer patients (www. success-studie.de), should provide more comprehensive knowledge of the CTC-based tailoring of treatment.

Recent studies have revealed that CTCs may be linked to both cancer stem cells and the EMT process [13, 145], which adds additional value to the clinical utility of CTCs. The expression of EMT-related proteins, such as vimentin or TWIST1, has been found in CTCs obtained from breast cancer patients [146, 147]. CTCs with a hybrid (epithelial/mesenchymal) phenotype have also been found in patients with metastatic non-small cell lung cancer [148] and prostate cancer [9]. Interestingly, mesenchymal markers on CTCs occur more frequently in metastatic breast cancer than in breast cancer at an early stage [146], and allowed more accurate prediction of worse prognosis than the expression of epithelial markers alone [147]. In patients with primary breast cancer the overexpression of EMT-inducing transcription factors (TWIST1, SNAIL1, SLUG, ZEB1, and FOXC2) was more frequently detected in those who received neoadjuvant therapies than in those who did not, which suggests that neoadajuvant therapy is unable to eliminate CTCs undergoing EMT [149]. Moreover, the overexpression of EMT markers on CTCs was often accompanied by the presence of the stem cell markers ALDH1 in breast cancer at all stages of the disease [6-8] and CD133 in castration-resistant prostate cancer [9]. The existence of a subpopulation of CTCs with a stem cell-like $\mathrm{CD} 44^{+} \mathrm{CD} 24^{-}$phenotype and ALDH1 expression has also been described in metastatic breast cancer [150]. In addition, CTCs from patients with primary or metastatic breast cancer have been shown to express receptors and activated signaling kinases of the EGFR/HER2/PI3K/Akt pathway [142], which is one of the major pathways involved in the regulation of mammary stem/progenitor cells, promoting the proliferation and inhibition of apoptosis [151]. It has recently been demonstrated that, similarly to mammary stem cells [152], CTCs found in primary breast cancer patients are mostly triple-negative - estrogen receptor-negative, progesterone receptor-negative and HER2-negative [153].
The data concerning the occurrence of EMT in DTCs are scarce and not conclusive. Cell lines derived from DTCs of breast cancer patients show low expression of CK8, CK18 and CK19 cytokeratins, and increased levels of vimentin, which resembles characteristic features of EMT $[154,155]$. Moreover, elevated TWIST1 expression was found in EpCAM-enriched bone marrow samples [156], which suggests the occurrence of partial EMT. Additionally, an increased tumor-initiating ability of DTCs, recognized as the stem cell phenotype $\left(\mathrm{CD} 44^{+} \mathrm{CD} 24^{-}\right)$, was detected in both the DTC-derived cell lines [156] and the CK19-positive DTCs isolated from the bone marrow of early-stage breast cancer patients [157].

To sum up, the expression of stemness markers and EMT markers in CTCs might provide them with strong metastasis-initiating properties, and render them resistant to conventional anticancer therapies. The described findings also demonstrate that current CTC detection methods may lead to underestimation of the significance of the most important, EMT-positive, subpopulation of CTCs involved in cancer dissemination. This could also explain why CTCs are currently being undetected in about $30 \%$ of metastatic breast cancer patients [141]. Thus, the fact that CTCs show stemness and EMT features is of fundamental importance for their reliable detection, which in turn can be used as a tool for tailoring effective cancer treatment.

\section{Seed and Soil Hypothesis}

Metastasis is a complex process requiring interplay between the seeded tumor cells and the microenvironment at the secondary site. Although the ability of tumor cells to migrate, either intrinsically or conferred through EMT, is of key importance for tumor progression, it is not sufficient to set up secondary tumor lesions in different anatomical compartments. A growing body of evidence indicates that the interaction between tumor cells and the local microenvironment at the secondary site leads to the development of premetastatic niches - compartment(s) of the body with a microenvironment which allows the malignant cells to develop metastases. Common sites of metastases in breast cancer include organs such as bone, the liver, lung and brain [158-160]. More than a hundred years ago, Stephen Paget noticed that the pattern of metastases produced by different neoplasms is not random. In his 'seed and soil' hypothesis, Paget claimed that certain tumor cells ('seed') have an affinity for the microenvironment of specific organs ('soil'), and only when the 
'seed' and the 'soil' are compatible can metastases occur [107]. He claimed that the 'soil' properties may be of great value in understanding cancer metastasis, revealing that certain populations of cells ('seed') may be expected to play a central role in the formation of secondary tumors. Those cells may be predestinated to establish metastases in specific organs already at the initial stages of tumor development [161, 162]. Moreover, it is now known that tumor cells can produce factors that lead to the establishment of premetastatic niches $[163,164]$. However, the mechanism allowing tumor cells to influence the behavior of microenvironment cells is poorly understood. Müller et al. [165] explain metastasis formation through an analogy with chemokines attracting immune cells to inflammation sites. A distinct pattern of chemokine receptor expression on tumor cells and their ligands in common sites of metastatic spread is critical for tumor progression [166]. For example, the receptor-ligand complex CXCR4-CXCL12 is well described in the context of breast cancer progression. CXCR4 is expressed on the surface of breast cancer cells [165], whereas CXCL12 is released by stromal cells in the target organs of breast cancer metastasis (bone, lung, brain, liver, lymph node) which indicates its role in targeted metastasis [165]. A high level of CXCR4 on tumor cells is correlated with poor prognosis in breast cancer patients because of its association with lymph node metastasis [167]. Moreover, it was observed that HER2, which positively correlates with metastasis and poor survival, enhanced the expression and function of CXCR4 by inhibiting its degradation [168]. The CXCR4 receptor is also considered a marker for stem cells and the subpopulation of cells expressing CXCR4 increases dramatically in secondary tumors [169]. Hence, CXCR4 expressed on stem cells allows them to follow the gradient of CXCL12 and 'seed' tumors in remote organs [170]. A recent work by Labelle et al. [171] shed a new light on the subject of the metastatic process. They demonstrated that the interactions of tumor cells with their microenvironment at the primary tumor site may also be sufficient to direct the tumor cells into the specific site of future metastasis. Platelet-derived signals (TGF- $\beta$ ) and direct cellcell contact were shown to be sufficient for effective metastasis of cancer cells.

\section{Summary}

Metastasis formation is a highly inefficient process as it requires gaining several unique features simultaneously. The tumor cells not only need to acquire increased motility and invasiveness, but also have to evade the adverse conditions they encounter. At first, the tumor cells that reached the circulatory system, CTCs, are in danger of death by anoikis [172, 173], destruction by immune system cells either in the bloodstream or after extravasation [174]. Moreover, not all the disseminated cells are able to initiate and sustain proliferation that can be later seen as a macrometastasis [112]. According to the cancer stem cell hypothesis, only a fraction of continuously proliferating cells can do so. The exact mechanisms that allow cancer cells to overcome those limitations and form a metastatic lesion are not fully understood. However, it seems that one way is through cancerous EMT which allows cells to: (1) become invasive and motile, (2) become resistant to anoikis, thus enabling separate cells to exist in the form of CTCs, and (3) gain stem cell properties needed to initiate metastatic growth at a distant site. All of the mentioned features can be found in both CTCs and CSCs, which suggests that stem cell-like cells can be generated by EMT occurring in a primary tumor [174]. Although the discussion on the definition of cancer stem cells is still ongoing, as it is not clear what a cancer stem cell really is, there are markers that define the population of cells showing increased tumorigenicity. As discussed before, $\mathrm{CD} 44^{+} / \mathrm{CD} 24^{-/ \text {low }}$ populations from breast cancer tumors can be referred to as possessing stem cell properties. Despite reproducible results indicating the presence of CD44 on stem cells, the protein seems to be one of many stemness markers.

Cancer stem cells may arise in different ways and during cancer development they can undergo genetic and epigenetic changes. This may result in the formation of different populations of CSCs which vary in their malignancy $[175,176]$. To test this hypothesis many more markers need to be studied, which will allow more precise characterization of the tumor-initiating ability of CSCs.

Interestingly, it has been shown that in breast cancer cells the expression of markers of a tumorigenic subpopulation can change, thus changing the tumorigenic cell into a nontumorigenic cell and vice versa. Nevertheless, the proportion of CSCs to non-stem cancer cells, which is typical for the cell line, is maintained [177]. In the case of CTCs, the presence of other markers (like ALDH1, OCT-4, NANOG, CD133, CXCR4, TWIST1, or vimentin) can allow further definition of a group with a higher degree of stemness or aggressiveness.

Understanding the process of metastasis formation requires broadening the knowledge of the individual steps of metastatic cascade. Even though the mechanism of cell migration - cohort migration, observed in tumors - 
seems to be reminiscent of a morphological program, single cells can also be detected in the circulation $[30,52]$. These solitary cells can be generated as a result of loss of E-cadherin, which is responsible for the shift into the individual (single cell) migration strategy [51]. It is yet to be determined to what extent the EMT process is necessary for metastasis formation, as non-EMT cells have been shown to cooperate with EMT cells in this process [55]. Moreover, a number of studies [reviewed in 30] have demonstrated that a full EMT is not necessary for successful invasion and metastasis.

The amount of data generated on cancer progression, including in vitro studies, animal models and cancer pa- tients, has shed new light on the complex process of metastasis formation. Better characterization of CTCs and CSCs seems necessary in order to develop new, more effective strategies of cancer eradication.

\section{Acknowledgments}

This work was supported by the National Centre for Research and Development LIDER/13/117/L-1/09/NCBiR/2010. In addition, this work was supported by the system project 'InnoDoktorant - Scholarships for PhD students, IIIrd edition'. The project is co-financed by the European Union in the frame of the European Social Fund.

\section{References}

1 Geiger TR, Peeper DS: Metastasis mechanisms. Biochim Biophys Acta 2009;1796: 293-308.

2 Thiery JP: Epithelial-mesenchymal transitions in tumour progression. Nat Rev Cancer 2002;2:442-454.

-3 Potenta S, Zeisberg E, Kalluri R: The role of endothelial-to-mesenchymal transition in cancer progression. Br J Cancer 2008;99: 1375-1379.

-4 Mani SA, Guo W, Liao MJ, Eaton EN, Ayyanan A, Zhou AY, Brooks M, Reinhard F, Zhang CC, Shipitsin M, Campbell LL, Polyak K, Brisken C, Yang J, Weinberg RA: The epithelial-mesenchymal transition generates cells with properties of stem cells. Cell 2008; 133:704-715.

5 Hollier BG, Evans K, Mani SA: The epithelial-to-mesenchymal transition and cancer stem cells: a coalition against cancer therapies. J Mammary Gland Biol Neoplasia 2009; 14:29-43.

6 Aktas B, Tewes M, Fehm T, Hauch S, Kimmig R, Kasimir-Bauer S: Stem cell and epithelial-mesenchymal transition markers are frequently overexpressed in circulating tumor cells of metastatic breast cancer patients. Breast Cancer Res 2009;11:R46.

$>7$ Raimondi C, Gradilone A, Naso G, Vincenzi B, Petracca A, Nicolazzo C, Palazzo A, Saltarelli R, Spremberg F, Cortesi E, Gazzaniga P: Epithelial-mesenchymal transition and stemness features in circulating tumor cells from breast cancer patients. Breast Cancer Res Treat 2011;130:449-455.

$\checkmark 8$ Kasimir-Bauer S, Hoffmann O, Wallwiener D, Kimmig R, Fehm T: Expression of stem cell and epithelial-mesenchymal transition markers in primary breast cancer patients with circulating tumor cells. Breast Cancer Res 2012;14:R15.

EMT: A Phenomenon Linking CTCs and CSCs
9 Armstrong AJ, Marengo MS, Oltean S, Kemeny G, Bitting RL, Turnbull JD, Herold CI, Marcom PK, George DJ, Garcia-Blanco MA: Circulating tumor cells from patients with advanced prostate and breast cancer display both epithelial and mesenchymal markers. Mol Cancer Res 2011;9:997-1007.

10 Hay ED: The mesenchymal cell, its role in the embryo, and the remarkable signaling mechanisms that create it. Dev Dyn 2005;233: 706-720.

11 Kalluri R: EMT: when epithelial cells decide to become mesenchymal-like cells. J Clin Invest 2009;119:1417-1419.

12 Kalluri R, Weinberg RA: The basics of epithelial-mesenchymal transition. J Clin Invest 2009;119:1420-1428.

13 Bonnomet A, Brysse A, Tachsidis A, Waltham M, Thompson EW, Polette M, Gilles C: Epithelial-to-mesenchymal transitions and circulating tumor cells. J Mammary Gland Biol Neoplasia 2010;15:261-273.

14 Thiery JP, Acloque H, Huang RY, Nieto MA: Epithelial-mesenchymal transitions in development and disease. Cell 2009;139:871-890.

15 Thiery JP, Sleeman JP: Complex networks orchestrate epithelial-mesenchymal transitions. Nat Rev Mol Cell Biol 2006;7:131-142.

16 Christofori G: New signals from the invasive front. Nature 2006;441:444-450.

17 Jechlinger M, Grunert S, Tamir IH, Janda E, Lüdemann S, Waerner T, Seither P, Weith A, Beug H, Kraut N: Expression profiling of epithelial plasticity in tumor progression. Oncogene 2003;22:7155-7169.

18 Lee JM, Dedhar S, Kalluri R, Thompson EW: The epithelial-mesenchymal transition: new insights in signaling, development, and disease. J Cell Biol 2006;172:973-981.

19 Micalizzi DS, Farabaugh SM, Ford HL: Epithelial-mesenchymal transition in cancer: parallels between normal development and tumor progression. J Mammary Gland Biol Neoplasia 2010;15:117-134.
20 Eigentler TK, Weide B, de Braud F, Spitaleri G, Romanini A, Pflugfelder A, GonzálezIglesias R, Tasciotti A, Giovannoni L, Schwager K, Lovato V, Kaspar M, Trachsel E, Menssen HD, Neri D, Garbe C: A dose-escalation and signal-generating study of the immunocytokine L19-IL2 in combination with dacarbazine for the therapy of patients with metastatic melanoma. Clin Cancer Res 2011; 17:7732-7742.

-21 Raimondi C, Gradilone A, Naso G, Vincenzi B, Petracca A, Nicolazzo C, Palazzo A, Saltarelli R, Spremberg F, Cortesi E, Gazzaniga P: Epithelial-mesenchymal transition and stemness features in circulating tumor cells from breast cancer patients. Breast Cancer Res Treat 2011;130:449-455.

22 Yang J, Weinberg RA: Epithelial-mesenchymal transition: at the crossroads of development and tumor metastasis. Dev Cell 2008; 14:818-829.

23 Moustakas A, Heldin CH: Signaling networks guiding epithelial-mesenchymal transitions during embryogenesis and cancer progression. Cancer Sci 2007;98:1512-1520.

24 Zavadil J, Böttinger EP: TGF-beta and epithelial-to-mesenchymal transitions. Oncogene 2005;24:5764-5774.

25 Massagué J: TGFbeta in cancer. Cell 2008; 134:215-230.

26 Thompson EW, Williams ED: EMT and MET in carcinoma - clinical observations, regulatory pathways and new models. Clin Exp Metastasis 2008;25:591-592.

27 Chaffer CL, Thompson EW, Williams ED: Mesenchymal to epithelial transition in development and disease. Cells Tissues Organs 2007;185:7-19.

28 Townsend TA, Wrana JL, Davis GE, Barnett JV: Transforming growth factor-beta-stimulated endocardial cell transformation is dependent on Par6c regulation of RhoA. J Biol Chem 2008;283:13834-13841. 
-29 Peinado H, Portillo F, Cano A: Transcriptional regulation of cadherins during development and carcinogenesis. Int J Dev Biol 2004;48:365-375.

-30 Christiansen JJ, Rajasekaran AK: Reassessing epithelial to mesenchymal transition as a prerequisite for carcinoma invasion and metastasis. Cancer Res 2006;66:8319-8326.

-31 Haraguchi M, Okubo T, Miyashita Y, Miyamoto Y, Hayashi M, Crotti TN, McHugh KP, Ozawa M: Snail regulates cell-matrix adhesion by regulation of the expression of integrins and basement membrane proteins. J Biol Chem 2008;283:23514-23523.

-32 Sternlicht MD: Key stages in mammary gland development: the cues that regulate ductal branching morphogenesis. Breast Cancer Res 2006;8:201.

-33 Hennighausen L, Robinson GW: Signaling pathways in mammary gland development. Dev Cell 2001;1:467-475.

>34 Zeisberg EM, Potenta S, Xie L, Zeisberg M, Kalluri R: Discovery of endothelial to mesenchymal transition as a source for carcinoma-associated fibroblasts. Cancer Res 2007; 67:10123-10128.

- 35 Zeisberg EM, Tarnavski O, Zeisberg M, Dorfman AL, McMullen JR, Gustafsson E, Chandraker A, Yuan X, Pu WT, Roberts AB, Neilson EG, Sayegh MH, Izumo S, Kalluri R: Endothelial-to-mesenchymal transition contributes to cardiac fibrosis. Nat Med 2007;13: 952-961.

-36 Zeisberg EM, Potenta SE, Sugimoto H, Zeisberg M, Kalluri R: Fibroblasts in kidney fibrosis emerge via endothelial-to-mesenchymal transition. J Am Soc Nephrol 2008;19: 2282-2287.

$\checkmark 37$ Kim KK, Kugler MC, Wolters PJ, Robillard L, Galvez MG, Brumwell AN, Sheppard D, Chapman HA: Alveolar epithelial cell mesenchymal transition develops in vivo during pulmonary fibrosis and is regulated by the extracellular matrix. Proc Natl Acad Sci USA 2006;103:13180-13185.

>38 Condeelis J, Segall JE: Intravital imaging of cell movement in tumours. Nat Rev Cancer 2003;3:921-930.

>39 Brabletz T, Jung A, Reu S, Porzner M, Hlubek F, Kunz-Schughart LA, Knuechel R, Kirchner T: Variable beta-catenin expression in colorectal cancers indicates tumor progression driven by the tumor environment. Proc Natl Acad Sci USA 2001;98:10356-10361.

-40 Trimboli AJ, Fukino K, de Bruin A, Wei G, Shen L, Tanner SM, Creasap N, Rosol TJ, Robinson ML, Eng C, Ostrowski MC, Leone G: Direct evidence for epithelial-mesenchymal transitions in breast cancer. Cancer Res 2008;68:937-945.

-41 Gregory PA, Bracken CP, Bert AG, Goodall GJ: MicroRNAs as regulators of epithelialmesenchymal transition. Cell Cycle 2008; 7: 3112-3118.
42 Wellner U, Schubert J, Burk UC, Schmalhofer O, Zhu F, Sonntag A, Waldvogel B, Vannier C, Darling D, zur Hausen A, Brunton VG, Morton J, Sansom O, Schüler J, Stemmler MP, Herzberger C, Hopt U, Keck T, Brabletz S, Brabletz T: The EMT-activator ZEB1 promotes tumorigenicity by repressing stemness-inhibiting microRNAs. Nat Cell Biol 2009; 11:1487-1495.

43 Creighton CJ, Chang JC, Rosen JM: Epithelial-mesenchymal transition (EMT) in tumorinitiating cells and its clinical implications in breast cancer. J Mammary Gland Biol Neoplasia 2010;15:253-260.

44 De Wever O, Pauwels P, De Craene B, Sabbah M, Emami S, Redeuilh G, Gespach C, Bracke M, Berx G: Molecular and pathological signatures of epithelial-mesenchymal transitions at the cancer invasion front. Histochem Cell Biol 2008;130:481-494.

-45 Beerling E, Ritsma L, Vrisekoop N, Derksen PW, van Rheenen J: Intravital microscopy: new insights into metastasis of tumors. J Cell Sci 2011;124:299-310.

-46 Chao YL, Shepard CR, Wells A: Breast carcinoma cells re-express E-cadherin during mesenchymal to epithelial reverting transition. Mol Cancer 2010;9:179.

47 Chaffer CL, Brennan JP, Slavin JL, Blick T, Thompson EW, Williams ED: Mesenchymal-to-epithelial transition facilitates bladder cancer metastasis: role of fibroblast growth factor receptor-2. Cancer Res 2006; 66:11271-11278.

48 Hudson LG, Zeineldin R, Stack MS: Phenotypic plasticity of neoplastic ovarian epithelium: unique cadherin profiles in tumor progression. Clin Exp Metastasis 2008;25:643655.

49 Hugo H, Ackland ML, Blick T, Lawrence MG, Clements JA, Williams ED, Thompson EW: Epithelial-mesenchymal and mesenchymal-epithelial transitions in carcinoma progression. J Cell Physiol 2007;213:374383.

50 Klymkowsky MW, Savagner P: Epithelialmesenchymal transition: a cancer researcher's conceptual friend and foe. Am J Pathol 2009; 174: 1588-1593.

51 Friedl P, Wolf K: Tumour-cell invasion and migration: diversity and escape mechanisms. Nat Rev Cancer 2003;3:362-374.

52 Friedl P, Gilmour D: Collective cell migration in morphogenesis, regeneration and cancer. Nat Rev Mol Cell Biol 2009;10:445457.

53 Ewald AJ, Brenot A, Duong M, Chan BS, Werb Z: Collective epithelial migration and cell rearrangements drive mammary branching morphogenesis. Dev Cell 2008; 14: 570-581.

54 Friedl P, Noble PB, Walton PA, Laird DW, Chauvin PJ, Tabah RJ, Black M, Zänker KS: Migration of coordinated cell clusters in mesenchymal and epithelial cancer explants in vitro. Cancer Res 1995;55:4557-4560.
55 Tsuji T, Ibaragi S, Hu GF: Epithelial-mesenchymal transition and cell cooperativity in metastasis. Cancer Res 2009;69:7135-7139.

56 Wicha MS, Liu S, Dontu G: Cancer stem cells: an old idea - a paradigm shift. Cancer Res 2006;66:1883-1890, discussion 18951886.

57 Al-Hajj M, Wicha MS, Benito-Hernandez A, Morrison SJ, Clarke MF: Prospective identification of tumorigenic breast cancer cells. Proc Natl Acad Sci USA 2003;100:39833988.

58 Bonnet D, Dick JE: Human acute myeloid leukemia is organized as a hierarchy that originates from a primitive hematopoietic cell. Nat Med 1997;3:730-737.

59 Bomken S, Fiser K, Heidenreich O, Vormoor J: Understanding the cancer stem cell. Br J Cancer 2010;103:439-445.

60 Nowell PC: The clonal evolution of tumor cell populations. Science 1976;194:23-28.

-61 Kakarala M, Wicha MS: Implications of the cancer stem-cell hypothesis for breast cancer prevention and therapy. J Clin Oncol 2008; 26:2813-2820.

62 Ward RJ, Dirks PB: Cancer stem cells: at the headwaters of tumor development. Annu Rev Pathol 2007;2:175-189.

63 Singh SK, Hawkins C, Clarke ID, Squire JA, Bayani J, Hide T, Henkelman RM, Cusimano MD, Dirks PB: Identification of human brain tumour initiating cells. Nature 2004;432: 396-401.

-64 Fang D, Nguyen TK, Leishear K, Finko R, Kulp AN, Hotz S, Van Belle PA, Xu X, Elder DE, Herlyn M: A tumorigenic subpopulation with stem cell properties in melanomas. Cancer Res 2005;65:9328-9337.

65 Collins AT, Berry PA, Hyde C, Stower MJ, Maitland NJ: Prospective identification of tumorigenic prostate cancer stem cells. Cancer Res 2005;65:10946-10951.

66 Gibbs CP, Kukekov VG, Reith JD, Tchigrinova O, Suslov ON, Scott EW, Ghivizzani SC, Ignatova TN, Steindler DA: Stem-like cells in bone sarcomas: implications for tumorigenesis. Neoplasia 2005;7:967-976.

67 Singh SK, Hawkins C, Clarke ID, Squire JA, Bayani J, Hide T, Henkelman RM, Cusimano MD, Dirks PB: Identification of human brain tumour initiating cells. Nature 2004;432: 396-401.

68 Hope KJ, Jin L, Dick JE: Acute myeloid leukemia originates from a hierarchy of leukemic stem cell classes that differ in self-renewal capacity. Nat Immunol 2004;5:738-743.

69 Dalerba P, Cho RW, Clarke MF: Cancer stem cells: models and concepts. Annu Rev Med 2007;58:267-284. 
-70 Li Y, Welm B, Podsypanina K, Huang S, Chamorro M, Zhang X, Rowlands T, Egeblad M, Cowin P, Werb Z, Tan LK, Rosen JM, Varmus HE: Evidence that transgenes encoding components of the Wnt signaling pathway preferentially induce mammary cancers from progenitor cells. Proc Natl Acad Sci USA 2003;100:15853-15858.

-71 Krivtsov AV, Twomey D, Feng Z, Stubbs MC, Wang Y, Faber J, Levine JE, Wang J, Hahn WC, Gilliland DG, Golub TR, Armstrong SA: Transformation from committed progenitor to leukaemia stem cell initiated by MLL-AF9. Nature 2006;442:818-822.

-72 Brabletz T, Jung A, Spaderna S, Hlubek F, Kirchner T: Opinion: migrating cancer stem cells - an integrated concept of malignant tumour progression. Nat Rev Cancer 2005;5: 744-749.

73 Kai K, Arima Y, Kamiya T, Saya H: Breast cancer stem cells. Breast Cancer 2010;17:8085.

-74 Abraham BK, Fritz P, McClellan M, Hauptvogel P, Athelogou M, Brauch H: Prevalence of CD44+/CD24-/low cells in breast cancer may not be associated with clinical outcome but may favor distant metastasis. Clin Cancer Res 2005;11:1154-1159.

-75 Honeth G, Bendahl PO, Ringnér M, Saal LH, Gruvberger-Saal SK, Lövgren K, Grabau D, Fernö M, Borg A, Hegardt C: The CD44+/ CD24- phenotype is enriched in basal-like breast tumors. Breast Cancer Res 2008; 10:R53.

-76 Damelin M, Geles KG, Follettie MT, Yuan P, Baxter M, Golas J, DiJoseph JF, Karnoub M, Huang S, Diesl V, Behrens C, Choe SE, Rios C, Gruzas J, Sridharan L, Dougher M, Kunz A, Hamann PR, Evans D, Armellino D, Khandke K, Marquette K, Tchistiakova L, Boghaert ER, Abraham RT, Wistuba II, Zhou BB: Delineation of a cellular hierarchy in lung cancer reveals an oncofetal antigen expressed on tumor-initiating cells. Cancer Res 2011;71:4236-4246.

-77 Hurt EM, Kawasaki BT, Klarmann GJ, Thomas SB, Farrar WL: CD44+ CD24prostate cells are early cancer progenitor/ stem cells that provide a model for patients with poor prognosis. Br J Cancer 2008;98: 756-765.

-78 Li C, Heidt DG, Dalerba P, Burant CF, Zhang L, Adsay V, Wicha M, Clarke MF, Simeone DM: Identification of pancreatic cancer stem cells. Cancer Res 2007;67:1030-1037.

-79 Zhang C, Li C, He F, Cai Y, Yang H: Identification of CD44+CD24+ gastric cancer stem cells. J Cancer Res Clin Oncol 2011;137: 1679-1686.

80 Dalerba P, Dylla SJ, Park IK, Liu R, Wang X, Cho RW, Hoey T, Gurney A, Huang EH, Simeone DM, Shelton AA, Parmiani G, Castelli C, Clarke MF: Phenotypic characterization of human colorectal cancer stem cells. Proc Natl Acad Sci USA 2007;104:1015810163.
81 Vermeulen L, Todaro M, de Sousa Mello F, Sprick MR, Kemper K, Perez Alea M, Richel DJ, Stassi G, Medema JP: Single-cell cloning of colon cancer stem cells reveals a multi-lineage differentiation capacity. Proc Natl Acad Sci USA 2008;105:13427-13432.

82 Choi D, Lee HW, Hur KY, Kim JJ, Park GS, Jang SH, Song YS, Jang KS, Paik SS: Cancer stem cell markers CD133 and CD24 correlate with invasiveness and differentiation in colorectal adenocarcinoma. World J Gastroenterol 2009; 15:2258-2264.

83 Kemper K, Grandela C, Medema JP: Molecular identification and targeting of colorectal cancer stem cells. Oncotarget 2010;1:387395.

84 Chute JP, Muramoto GG, Whitesides J, Colvin M, Safi R, Chao NJ, McDonnell DP: Inhibition of aldehyde dehydrogenase and retinoid signaling induces the expansion of human hematopoietic stem cells. Proc Natl Acad Sci USA 2006; 103:11707-11712.

85 Huang EH, Hynes MJ, Zhang T, Ginestier C, Dontu G, Appelman H, Fields JZ, Wicha MS, Boman BM: Aldehyde dehydrogenase 1 is a marker for normal and malignant human colonic stem cells (SC) and tracks SC overpopulation during colon tumorigenesis. Cancer Res 2009;69:3382-3389.

86 Kim MP, Fleming JB, Wang H, Abbruzzese JL, Choi W, Kopetz S, McConkey DJ, Evans DB, Gallick GE: ALDH activity selectively defines an enhanced tumor-initiating cell population relative to $\mathrm{CD} 133$ expression in human pancreatic adenocarcinoma. PLoS One 2011;6:e20636.

87 Vermeulen L, De Sousa E Melo F, van der Heijden M, Cameron K, de Jong JH, Borovski T, Tuynman JB, Todaro M, Merz C, Rodermond H, Sprick MR, Kemper K, Richel DJ, Stassi G, Medema JP: Wnt activity defines colon cancer stem cells and is regulated by the microenvironment. Nat Cell Biol 2010; 12:468-476.

88 Ginestier C, Hur MH, Charafe-Jauffret E, Monville F, Dutcher J, Brown M, Jacquemier J, Viens P, Kleer CG, Liu S, Schott A, Hayes D, Birnbaum D, Wicha MS, Dontu G: ALDH1 is a marker of normal and malignant human mammary stem cells and a predictor of poor clinical outcome. Cell Stem Cell 2007;1:555-567.

89 Liu Q, Li JG, Zheng XY, Jin F, Dong HT: Expression of CD133, PAX2, ESA, and GPR30 in invasive ductal breast carcinomas. Chin Med J (Engl) 2009;122:2763-2769.

90 Liu CG, Lu Y, Wang BB, Zhang YJ, Zhang RS, Chen B, Xu H, Jin F, Lu P: Clinical implications of stem cell gene Oct-4 expression in breast cancer. Ann Surg 2011;253:1165-1171.

91 Buommino E, Tirino V, De Filippis A, Silvestri F, Nicoletti R, Ciavatta ML, Pirozzi G, Tufano MA: 3-O-methylfunicone, from Penicillium pinophilum, is a selective inhibitor of breast cancer stem cells. Cell Prolif 2011;44: 401-409.
92 Kim JB, Sebastiano V, Wu G, Arauzo-Bravo MJ, Sasse P, Gentile L, Ko K, Ruau D, Ehrich $\mathrm{M}$, van den Boom D, Meyer J, Hubner K, Bernemann C, Ortmeier C, Zenke M, Fleischmann BK, Zaehres H, Scholer HR: Oct4induced pluripotency in adult neural stem cells. Cell 2009;136:411-419.

93 Liu CG, Lu Y, Wang BB, Zhang YJ, Zhang RS, Chen B, Xu H, Jin F, Lu P: Clinical implications of stem cell gene Oct-4 expression in breast cancer. Ann Surg 2011;253: $1165-1171$.

94 Kim RJ, Nam JS: OCT4 expression enhances features of cancer stem cells in a mouse model of breast cancer. Lab Anim Res 2011; 27:147-152.

95 Chambers I, Silva J, Colby D, Nichols J, Nijmeijer B, Robertson M, Vrana J, Jones K, Grotewold L, Smith A: Nanog safeguards pluripotency and mediates germline development. Nature 2007;450:1230-1234.

96 Takahashi K, Yamanaka S: Induction of pluripotent stem cells from mouse embryonic and adult fibroblast cultures by defined factors. Cell 2006;126:663-676.

\$97 Oskarsson T, Acharyya S, Zhang XHF, Vanharanta S, Tavazoie SF, Morris PG, Downey RJ, Manova-Todorova K, Brogi E, Massague J: Breast cancer cells produce tenascin $\mathrm{C}$ as a metastatic niche component to colonize the lungs. Nat Med 2011;17:867874.

98 Evangelista M, Tian H, de Sauvage FJ: The hedgehog signaling pathway in cancer. Clin Cancer Res 2006;12:5924-5928.

-99 Wright M, Calcagno A, Salcido C, Carlson M, Ambudkar S, Varticovski L: Brcal breast tumors contain distinct $\mathrm{CD} 44+$ / CD24- and CD133+ cells with cancer stem cell characteristics. Breast Cancer Res 2008; 10:R10.

100 Oztürk MA, Güven GS, Haznedaroglu IC: How hematopoietic stem cells know and act in cardiac microenvironment for stem cell plasticity? Impact of local renin-angiotensin systems. Med Hypotheses 2004;63:866874.

101 Visvader JE, Lindeman GJ: Cancer stem cells in solid tumours: accumulating evidence and unresolved questions. Nat Rev Cancer 2008;8:755-768.

102 Charafe-Jauffret E, Monville F, Ginestier C, Dontu G, Birnbaum D, Wicha MS: Cancer stem cells in breast: current opinion and future challenges. Pathobiology 2008;75:7584.

103 Liu R, Wang X, Chen GY, Dalerba P, Gurney A, Hoey T, Sherlock G, Lewicki J, Shedden K, Clarke MF: The prognostic role of a gene signature from tumorigenic breastcancer cells. N Engl J Med 2007;356:217226. 
104 Shipitsin M, Campbell LL, Argani P, Weremowicz S, Bloushtain-Qimron N, Yao J, Nikolskaya T, Serebryiskaya T, Beroukhim R, Hu M, Halushka MK, Sukumar S, Parker LM, Anderson KS, Harris LN, Garber JE, Richardson AL, Schnitt SJ, Nikolsky Y, Gelman RS, Polyak K: Molecular definition of breast tumor heterogeneity. Cancer Cell 2007;11:259-273.

105 Ponti D, Costa A, Zaffaroni N, Pratesi G, Petrangolini G, Coradini D, Pilotti S, Pierotti MA, Daidone MG: Isolation and in vitro propagation of tumorigenic breast cancer cells with stem/progenitor cell properties. Cancer Res 2005;65:5506-5511.

- 106 Allard WJ, Matera J, Miller MC, Repollet M, Connelly MC, Rao C, Tibbe AGJ, Uhr JW, Terstappen LWMM: Tumor cells circulate in the peripheral blood of all major carcinomas but not in healthy subjects or patients with nonmalignant diseases. Clin Cancer Res 2004;10:6897-6904.

107 Paget S: The distribution of secondary growths in cancer of the breast. Lancet 1889;133:571-573.

108 Kim MY, Oskarsson T, Acharyya S, Nguyen DX, Zhang XH, Norton L, Massague J: Tumor self-seeding by circulating cancer cells. Cell 2009;139:1315-1326.

109 Ross JS, Slodkowska EA: Circulating and disseminated tumor cells in the management of breast cancer. Am J Clin Pathol 2009;132:237-245.

110 Braun S, Vogl FD, Naume B, Janni W, Osborne MP, Coombes RC, Schlimok G, Diel IJ, Gerber B, Gebauer G, Pierga J-Y, Marth C, Oruzio D, Wiedswang G, Solomayer E-F, Kundt G, Strobl B, Fehm T, Wong GYC, Bliss J, Vincent-Salomon A, Pantel K: A pooled analysis of bone marrow micrometastasis in breast cancer. N Engl J Med 2005; 353:793-802.

- 111 Chang YS, di Tomaso E, McDonald DM, Jones R, Jain RK, Munn LL: Mosaic blood vessels in tumors: frequency of cancer cells in contact with flowing blood. Proc Natl Acad Sci USA 2000;97:14608-14613.

-112 Luzzi KJ, MacDonald IC, Schmidt EE, Kerkvliet N, Morris VL, Chambers AF, Groom AC: Multistep nature of metastatic inefficiency: dormancy of solitary cells after successful extravasation and limited survival of early micrometastases. Am J Pathol 1998;153:865-873.

- 113 Glinsky VV, Glinsky GV, Glinskii OV, Huxley VH, Turk JR, Mossine VV, Deutscher SL, Pienta KJ, Quinn TP: Intravascular metastatic cancer cell homotypic aggregation at the sites of primary attachment to the endothelium. Cancer Res 2003;63:3805-3811.

- 114 Berezovskaya O, Schimmer AD, Glinskii AB, Pinilla C, Hoffman RM, Reed JC, Glinsky GV: Increased expression of apoptosis inhibitor protein XIAP contributes to anoikis resistance of circulating human prostate cancer metastasis precursor cells. Cancer Res 2005;65:2378-2386.
115 Ashworth T: A case of cancer in which cells similar to those in the tumours were seen in the blood after death. Aust Med J 1869;14: 146-149.

116 Bednarz-Knoll N, Alix-Panabieres C, Pantel K: Clinical relevance and biology of circulating tumor cells. Breast Cancer Res 2011;13:228.

117 Pantel K, Alix-Panabieres C: Circulating tumour cells in cancer patients: challenges and perspectives. Trends Mol Med 2010;16: 398-406.

118 Edwards DP, Grzyb KT, Dressler LG, Mansel RE, Zava DT, Sledge GW, McGuire WL: Monoclonal antibody identification and characterization of a $\mathrm{Mr}$ 43,000 membrane glycoprotein associated with human breast cancer. Cancer Res 1986;46:1306-1317.

119 Packeisen J, Kaup-Franzen C, Knieriem HJ: Detection of surface antigen 17-1A in breast and colorectal cancer. Hybridoma 1999;18: 37-40.

120 Sieuwerts AM, Kraan J, Bolt J, van der Spoel P, Elstrodt F, Schutte M, Martens JWM, Gratama J-W, Sleijfer S, Foekens JA: Antiepithelial cell adhesion molecule antibodies and the detection of circulating normallike breast tumor cells. J Natl Cancer Inst 2009;101:61-66.

121 Mostert B, Kraan J, Bolt-de Vries J, van der Spoel P, Sieuwerts AM, Schutte M, Timmermans A, Foekens R, Martens J, Gratama J-W, Foekens J, Sleijfer S: Detection of circulating tumor cells in breast cancer may improve through enrichment with antiCD146. Breast Cancer Res Treat 2011;127: 33-41.

122 Mikolajczyk SD, Millar LS, Tsinberg P, Coutts SM, Zomorrodi M, Pham T, Bischoff FZ, Pircher TJ: Detection of EpCAM-negative and cytokeratin-negative circulating tumor cells in peripheral blood. J Oncol 2011;2011:252361.

123 Xi L, Nicastri DG, El-Hefnawy T, Hughes SJ, Luketich JD, Godfrey TE: Optimal markers for real-time quantitative reverse transcription PCR detection of circulating tumor cells from melanoma, breast, colon, esophageal, head and neck, and lung cancers. Clin Chem 2007;53:1206-1215.

124 Liotta LA, Kleinerman J, Saidel GM: Quantitative relationships of intravascular tumor cells, tumor vessels, and pulmonary metastases following tumor implantation. Cancer Res 1974;34:997-1004.

125 Stott SL, Lee RJ, Nagrath S, Yu M, Miyamoto DT, Ulkus L, Inserra EJ, Ulman $\mathrm{M}$, Springer S, Nakamura Z, Moore AL, Tsukrov DI, Kempner ME, Dahl DM, Wu CL, Iafrate AJ, Smith MR, Tompkins RG, Sequist LV, Toner M, Haber DA, Maheswaran $\mathrm{S}$ : Isolation and characterization of circulating tumor cells from patients with localized and metastatic prostate cancer. Sci Transl Med 2010;2:25ra23.
126 Cristofanilli M, Budd GT, Ellis MJ, Stopeck A, Matera J, Miller MC, Reuben JM, Doyle GV, Allard WJ, Terstappen LWMM, Hayes DF: Circulating tumor cells, disease progression, and survival in metastatic breast cancer. N Engl J Med 2004;351:781-791.

127 Pierga JY, Hajage D, Bachelot T, Delaloge S, Brain E, Campone M, Diéras V, Rolland E, Mignot L, Mathiot C, Bidard FC: High independent prognostic and predictive value of circulating tumor cells compared with serum tumor markers in a large prospective trial in first-line chemotherapy for metastatic breast cancer patients. Ann Oncol 2011, E-pub ahead of print.

128 Giuliano M, Giordano A, Jackson S, Hess K, De Giorgi U, Mego M, Handy B, Ueno N, Alvarez R, De Laurentiis M, De Placido S, Valero V, Hortobagyi G, Reuben J, Cristofanilli M: Circulating tumor cells as prognostic and predictive markers in metastatic breast cancer patients receiving first-line systemic treatment. Breast Cancer Res 2011;13:R67.

129 Ignatiadis M, Kallergi G, Ntoulia M, Perraki M, Apostolaki S, Kafousi M, Chlouverakis G, Stathopoulos E, Lianidou E, Georgoulias V, Mavroudis D: Prognostic value of the molecular detection of circulating tumor cells using a multimarker reverse transcription-PCR assay for cytokeratin 19, mammaglobin A, and HER2 in early breast cancer. Clin Cancer Res 2008;14:25932600.

130 Cohen SJ, Punt CJA, Iannotti N, Saidman BH, Sabbath KD, Gabrail NY, Picus J, Morse MA, Mitchell E, Miller MC, Doyle GV, Tissing H, Terstappen LWMM, Meropol NJ: Prognostic significance of circulating tumor cells in patients with metastatic colorectal cancer. Ann Oncol 2009;20: 1223-1229.

131 Scher HI, Jia X, de Bono JS, Fleisher M, Pienta KJ, Raghavan D, Heller G: Circulating tumour cells as prognostic markers in progressive, castration-resistant prostate cancer: a reanalysis of IMMC38 trial data. Lancet Oncol 2009;10:233-239.

132 Goodman OB Jr, Fink LM, Symanowski JT, Wong B, Grobaski B, Pomerantz D, Ma Y, Ward DC, Vogelzang NJ: Circulating tumor cells in patients with castration-resistant prostate cancer baseline values and correlation with prognostic factors. Cancer Epidemiol Biomarkers Prev 2009;18:19041913.

133 Hofman V, Bonnetaud C, Ilie MI, Vielh P, Vignaud JM, Flejou JF, Lantuejoul S, Piaton E, Mourad N, Butori C, Selva E, Poudenx M, Sibon S, Kelhef S, Venissac N, Jais JP, Mouroux J, Molina TJ, Hofman P: Preoperative circulating tumor cell detection using the isolation by size of epithelial tumor cell method for patients with lung cancer is a new prognostic biomarker. Clin Cancer Res 2011;17:827-835. 
134 Hofman V, Ilie MI, Long E, Selva E, Bonnetaud C, Molina T, Venissac N, Mouroux J, Vielh P, Hofman P: Detection of circulating tumor cells as a prognostic factor in patients undergoing radical surgery for nonsmall-cell lung carcinoma: comparison of the efficacy of the CellSearch Assay and the isolation by size of epithelial tumor cell method. Int J Cancer 2011;129:1651-1660.

135 Pierga J-Y, Bidard F-C, Mathiot C, Brain E, Delaloge S, Giachetti S, de Cremoux P, Salmon R, Vincent-Salomon A, Marty M: Circulating tumor cell detection predicts early metastatic relapse after neoadjuvant chemotherapy in large operable and locally advanced breast cancer in a phase II randomized trial. Clin Cancer Res 2008; 14: 7004-7010.

-136 Maheswaran S, Sequist LV, Nagrath S, Ulkus L, Brannigan B, Collura CV, Inserra E, Diederichs S, Iafrate AJ, Bell DW, Digumarthy S, Muzikansky A, Irimia D, Settleman J, Tompkins RG, Lynch TJ, Toner M, Haber DA: Detection of mutations in EGFR in circulating lung-cancer cells. N Engl J Med 2008;359:366-377.

137 Liu MC, Shields PG, Warren RD, Cohen P, Wilkinson M, Ottaviano YL, Rao SB, EngWong J, Seillier-Moiseiwitsch F, Noone $\mathrm{AM}$, Isaacs C: Circulating tumor cells: a useful predictor of treatment efficacy in metastatic breast cancer. J Clin Oncol 2009; 27:5153-5159.

-138 Budd GT, Cristofanilli M, Ellis MJ, Stopeck A, Borden E, Miller MC, Matera J, Repollet M, Doyle GV, Terstappen LWMM, Hayes DF: Circulating tumor cells versus imaging - predicting overall survival in metastatic breast cancer. Clin Cancer Res 2006;12: 6403-6409.

-139 Hayes DF, Cristofanilli M, Budd GT, Ellis MJ, Stopeck A, Miller MC, Matera J, Allard WJ, Doyle GV, Terstappen LWWM: Circulating tumor cells at each follow-up time point during therapy of metastatic breast cancer patients predict progression-free and overall survival. Clin Cancer Res 2006; 12:4218-4224.

140 Riethdorf S, Muller V, Zhang L, Rau T, Loibl S, Komor M, Roller M, Huober J, Fehm T, Schrader I, Hilfrich J, Holms F, Tesch H, Eidtmann H, Untch $M$, von Minckwitz G, Pantel K: Detection and HER2 expression of circulating tumor cells: prospective monitoring in breast cancer patients treated in the neoadjuvant $\mathrm{Ge}$ parQuattro trial. Clin Cancer Res 2010;16: 2634-2645.

141 Fehm T, Muller V, Aktas B, Janni W, Schneeweiss A, Stickeler E, Lattrich C, Lohberg CR, Solomayer E, Rack B, Riethdorf S, Klein C, Schindlbeck C, Brocker K, Kasimir-Bauer S, Wallwiener D, Pantel K: HER2 status of circulating tumor cells in patients with metastatic breast cancer: a prospective, multicenter trial. Breast Cancer Res Treat 2010;124:403-412.
142 Kallergi G, Agelaki S, Kalykaki A, Stournaras C, Mavroudis D, Georgoulias V: Phosphorylated EGFR and PI3K/Akt signaling kinases are expressed in circulating tumor cells of breast cancer patients. Breast Cancer Res 2008;10:R80.

143 Aktas B, Müller V, Tewes M, Zeitz J, Kasimir-Bauer S, Loehberg CR, Rack B, Schneeweiss A, Fehm T: Comparison of estrogen and progesterone receptor status of circulating tumor cells and the primary tumor in metastatic breast cancer patients. Gynecol Oncol 2011;122:356-360.

144 Liu Z, Fusi A, Schmittel A, Tinhofer I, Schneider A, Keilholz U: Eradication of EGFR-positive circulating tumor cells and objective tumor response with lapatinib and capecitabine. Cancer Biol Ther 2010; 10:860-864.

145 Blick T, Hugo H, Widodo E, Waltham M, Pinto C, Mani S, Weinberg R, Neve R, Lenburg M, Thompson E: Epithelial mesenchymal transition traits in human breast cancer cell lines parallel the CD44hi/CD24lo/stem cell phenotype in human breast cancer. J Mammary Gland Biol Neoplasia 2010;15:235-252.

146 Kallergi G, Papadaki M, Politaki E, Mavroudis D, Georgoulias V, Agelaki S: Epithelial to mesenchymal transition markers expressed in circulating tumour cells of early and metastatic breast cancer patients. Breast Cancer Res 2011;13:R59.

147 Gradilone A, Raimondi C, Nicolazzo C, Petracca A, Gandini O, Vincenzi B, Naso G, Aglianò AM, Cortesi E, Gazzaniga P: Circulating tumour cells lacking cytokeratin in breast cancer: the importance of being mesenchymal. J Cell Mol Med 2011;15: 1066-1070.

148 Lecharpentier A, Vielh P, Perez-Moreno P, Planchard D, Soria JC, Farace F: Detection of circulating tumour cells with a hybrid (epithelial/mesenchymal) phenotype in patients with metastatic non-small cell lung cancer. Br J Cancer 2011;105:1338-1341.

149 Mego M, Mani SA, Lee BN, Li C, Evans KW, Cohen EN, Gao H, Jackson SA, Giordano A, Hortobagyi GN, Cristofanilli M, Lucci A, Reuben JM: Expression of epithelial-mesenchymal transition-inducing transcription factors in primary breast cancer: the effect of neoadjuvant therapy. Int J Cancer 2012;130:808-816.

150 Theodoropoulos PA, Polioudaki H, Agelaki S, Kallergi G, Saridaki Z, Mavroudis D, Georgoulias V: Circulating tumor cells with a putative stem cell phenotype in peripheral blood of patients with breast cancer. Cancer Lett 2010;288:99-106.

151 Korkaya H, Paulson A, Charafe-Jauffret E, Ginestier C, Brown M, Dutcher J, Clouthier SG, Wicha MS: Regulation of mammary stem/progenitor cells by PTEN/Akt/beta-catenin signaling. PLoS Biol 2009; 7:e1000121.
152 Lim E, Vaillant F, Wu D, Forrest NC, Pal B, Hart AH, Asselin-Labat M-L, Gyorki DE, Ward T, Partanen A, Feleppa F, Huschtscha LI, Thorne HJ, Fox SB, Yan M, French JD, Brown MA, Smyth GK, Visvader JE, Lindeman GJ: Aberrant luminal progenitors as the candidate target population for basal tumor development in BRCA1 mutation carriers. Nat Med 2009;15:907913.

153 Fehm T, Hoffmann O, Aktas B, Becker S, Solomayer EF, Wallwiener D, Kimmig R, Kasimir-Bauer S: Detection and characterization of circulating tumor cells in blood of primary breast cancer patients by RTPCR and comparison to status of bone marrow disseminated cells. Breast Cancer Res 2009;11:R59.

154 Willipinski-Stapelfeldt B, Riethdorf S, Assmann V, Woelfle U, Rau T, Sauter G, Heukeshoven J, Pantel K: Changes in cytoskeletal protein composition indicative of an epithelial-mesenchymal transition in human micrometastatic and primary breast carcinoma cells. Clin Cancer Res 2005;11:8006-8014.

155 Bartkowiak K, Wieczorek M, Buck F, Harder S, Moldenhauer J, Effenberger KE, Pantel K, Peter-Katalinic J, Brandt BH: Twodimensional differential gel electrophoresis of a cell line derived from a breast cancer micrometastasis revealed a stem/progenitor cell protein profile. J Proteome Res 2009;8:2004-2014.

156 Bartkowiak K, Effenberger KE, Harder S, Andreas A, Buck F, Peter-Katalinic J, Pantel $\mathrm{K}$, Brandt BH: Discovery of a novel unfolded protein response phenotype of cancer stem/progenitor cells from the bone marrow of breast cancer patients. J Proteome Res 2010;9:3158-3168.

157 Balic M, Lin H, Young L, Hawes D, Giuliano A, McNamara G, Datar RH, Cote RJ: Most early disseminated cancer cells detected in bone marrow of breast cancer patients have a putative breast cancer stem cell phenotype. Clin Cancer Res 2006;12: 5615-5621.

158 Lacroix M: Significance, detection and markers of disseminated breast cancer cells. Endocr Relat Cancer 2006; 13:10331067.

159 Solomayer EF, Diel IJ, Meyberg GC, Gollan C, Bastert G: Metastatic breast cancer: clinical course, prognosis and therapy related to the first site of metastasis. Breast Cancer Res Treat 2000;59:271-278.

160 Mundy GR: Metastasis to bone: causes, consequences and therapeutic opportunities. Nat Rev Cancer 2002;2:584-593.

161 Weigelt B, Hu Z, He X, Livasy C, Carey LA, Ewend MG, Glas AM, Perou CM, Van't Veer LJ: Molecular portraits and 70-gene prognosis signature are preserved throughout the metastatic process of breast cancer. Cancer Res 2005;65:9155-9158. 
162 Allinen M, Beroukhim R, Cai L, Brennan C, Lahti-Domenici J, Huang H, Porter D, Hu M, Chin L, Richardson A, Schnitt S, Sellers WR, Polyak K: Molecular characterization of the tumor microenvironment in breast cancer. Cancer Cell 2004;6:17-32.

163 Kaplan RN, Riba RD, Zacharoulis S, Bramley $\mathrm{AH}$, Vincent L, Costa C, MacDonald DD, Jin DK, Shido K, Kerns SA, Zhu Z, Hicklin D, Wu Y, Port JL, Altorki N, Port ER, Ruggero D, Shmelkov SV, Jensen KK, Rafii S, Lyden D: VEGFR1-positive haematopoietic bone marrow progenitors initiate the pre-metastatic niche. Nature 2005;438: 820-827.

164 Hiratsuka S, Watanabe A, Aburatani H, Maru Y: Tumour-mediated upregulation of chemoattractants and recruitment of myeloid cells predetermines lung metastasis. Nat Cell Biol 2006;8:1369-1375.

165 Müller A, Homey B, Soto H, Ge N, Catron D, Buchanan ME, McClanahan T, Murphy E, Yuan W, Wagner SN, Barrera JL, Mohar A, Verástegui E, Zlotnik A: Involvement of chemokine receptors in breast cancer metastasis. Nature 2001;410:50-56.
166 Orimo A, Weinberg RA: Stromal fibroblasts in cancer: a novel tumor-promoting cell type. Cell Cycle 2006;5:1597-1601.

167 Liu Y, Ji R, Li J, Gu Q, Zhao X, Sun T, Wang J, Du Q, Sun B: Correlation effect of EGFR and CXCR4 and CCR7 chemokine receptors in predicting breast cancer metastasis and prognosis. J Exp Clin Cancer Res 2010; 29:16.

168 Li YM, Pan Y, Wei Y, Cheng X, Zhou BP, Tan M, Zhou X, Xia W, Hortobagyi GN, Yu D, Hung MC: Upregulation of CXCR4 is essential for HER2-mediated tumor metastasis. Cancer Cell 2004;6:459-469.

169 Balkwill F: The significance of cancer cell expression of the chemokine receptor CXCR4. Semin Cancer Biol 2004;14:171179.

170 Ceradini DJ, Gurtner GC: Homing to hypoxia: HIF-1 as a mediator of progenitor cell recruitment to injured tissue. Trends Cardiovasc Med 2005;15:57-63.
171 Labelle M, Begum S, Hynes RO: Direct signaling between platelets and cancer cells induces an epithelial-mesenchymal-like transition and promotes metastasis. Cancer Cell 2011;20:576-590.

172 Paterlini-Brechot P, Benali NL: Circulating tumor cells (CTC) detection: clinical impact and future directions. Cancer Lett 2007;253:180-204.

173 Grivennikov SI, Greten FR, Karin M: Immunity, inflammation, and cancer. Cell 2010;140:883-899.

174 Chaffer CL, Weinberg RA: A perspective on cancer cell metastasis. Science 2011;331: 1559-1564.

175 Clevers H: The cancer stem cell: premises, promises and challenges. Nat Med 2011;17: 313-319.

176 Campbell LL, Polyak K: Breast tumor heterogeneity: cancer stem cells or clonal evolution? Cell Cycle 2007;6:2332-2338.

177 Iliopoulos D, Hirsch HA, Wang G, Struhl $\mathrm{K}$ : Inducible formation of breast cancer stem cells and their dynamic equilibrium with non-stem cancer cells via IL6 secretion. Proc Natl Acad Sci USA 2011;108: 1397-1402. 